Огляди літератури, оригінальні дослідження, погляд на проблему, випадок з практики, короткі повідомлення УДК 616.127-005.8-06:616.132.2-005.6-076-089.819.6

DOI 10.11603/1811-2471.2021.v.i1.11921

\title{
РЕЗУЛЬТАТИ ГІСТОЛОГІЧНОГО АНАЛІЗУ ТРОМБІВ, ОТРИМАНИХ ПІД ЧАС ПЕРКУТАННОГО КОРОНАРНОГО ВТРУЧАННЯ: МОРФОЛОГІЧНІ ТА КЛІНІЧНІ ПАРАЛЕЛІ
}

\author{
๑М. В. Гребеник, Д. В. Жегестовська, З. М. Небесна, С. Б. Крамар \\ Тернопільський національний медичний університет імені І. Я. Горбачевського МОз України
}

РЕзЮМЕ. В основі патогенезу гострого коронарного синдрому лежить дестабілізація атеросклеротичної бляшки із подальшим тромбозом коронарної артерії. Із введенням у клінічну практику перкутанних коронарних втручань з'явилася можливість не лише швидко та ефективно відновлювати прохідність інфаркт-залежної судини, а й прижиттєво досліджувати структуру коронарних тромбів. Ця інформація $є$ цінною як для поглиблення розуміння патогенезу гострих коронарних подій, так і для прогнозу їх подальшого перебігу.

Мета - зіставити клінічні дані та гістологічну структуру тромбів у пацієнтів з гострим інфарктом міокарда (ГІМ).

Матеріал і методи. У дослідженні взяли участь 109 пацієнтів із діагнозом ГІМ. Придатний для гістологічного дослідження матеріал було отримано в 12 випадках. Відповідно до цього проводили аналіз зразків із визначенням гістологічного віку аспірованих тромбів, а також зіставлення їх морфологічних характеристик та клінічних даних пацієнтів.

Результати. У більшості випадків аспіровані тромби за макроскопічними показниками були віднесені до групи «червоних» - n=10 (83,3 \%). «Білі» тромби траплялися рідше - у 2 (16,7 \%) випадках, і були отримані лише у разі тривалості больового синдрому менше 2 годин. За даними світлової мікроскопії у $3(25,0 \%)$ випадках тромби класифікувалися, як «свіжі», всі вони були отримані в перші 6 годин з моменту розвитку больового синдрому. «Літичні» тромби виявлено у 7 (58,3 \%) пацієнтів і у 2 (16,7 \%) зразках відмічалися ознаки, характерні для “організованих» тромбів. При оцінці віддаленого прогнозу лише в одному випадку був епізод повторної госпіталізації з приводу повторного інфаркту міокарда у пацієнта із «червоним» тромбом, що за результатами світлової мікроскопії був віднесений до групи «літичних», тобто віком від 1 до 5 днів, незважаючи на тривалість періоду «сипмтом-балон» близько 3 годин.

Висновки. Нами було виявлено невідповідність гістологічного та клінічного віку коронарних тромбів. Також вдалося попередньо підтвердити існування зв'язку між структурою аспірованих тромбів та потенційним прогнозом перебігу гострого інфаркту міокарда, в тому числі й розвитку ускладнень у далекій перспективі.

КЛючОВІ СЛОВА: гострий інфаркт міокарда; коронарний тромб; морфологічні характеристики тромбів; черезшкірне перкутанне втручання.

Вступ. Ішемічна хвороба серця (IXC) та її ускладнення залишаються одними із найпоширеніших причин смертності серед дорослого населення в усьому світі [1]. Патогенетичною основою для розвитку IXC $\epsilon$ атеросклеротичне ураження коронарних артерій. Саме дестабілізація атеросклеротичної бляшки зумовлює активацію згортальної системи крові із подальшим утворенням тромбу, що перекриває просвіт коронарної артерії, призводячи до розвитку гострого інфаркту міокарда (ГІМ) [2]. На сьогодні «золотим стандартом» у тактиці ведення пацієнтів з ГІМ є проведення черезшкірного перкутанного коронарного втручання (ПКВ). ПКВ дозволяє не лише максимально ефективно і швидко відновлювати прохідність інфаркт-залежної артерії, а й забезпечує безпосередній доступ до тромбу в її просвіті. Це дозволило отримати коронарні тромби прижиттєво і дослідити патогенез цього явища.

Наявні клінічні рекомендації стосовно тактики ведення пацієнтів з ГІМ базуються на припущенні про існування безпосереднього зв'язку між початком утворення тромбу та часом з моменту розвитку больового синдрому, який сигналізує про ішемію міокарда. Втім, на сьогодні це твер- дження вважають суперечливим. Низка досліджень, що були сконцентровані на гістологічному аналізі матеріалу, аспірованого з коронарних артерій у пацієнтів з ГІМ, вказують на факт невідповідності тривалості болю та гістологічного віку тромбів [3-6]. Окрім того, структура тромбу потенційно може бути предиктором перебігу ГІМ та розвитку ускладнень у віддаленій перспективі [7-9].

Мета - провести клініко-морфологічне зіставлення структури і віку тромбів, отриманих під час проведення ПКВ у пацієнтів з ГІМ.

Матеріал і методи дослідження. У дослідженні взяли участь 109 пацієнтів, які були госпіталізовані в блок реанімації та інтенсивної терапії спеціалізованого кардіологічне відділення у період з жовтня 2018 по січень 2019 року з діагнозом «Гострий коронарний синдром з елевацією сегмента ST» (STEMI). В межах «терапевтичного вікна" (120 хвилин) було госпіталізовано лише 36 (33,0 \%) хворих. Причиною затримки в $60(55,1 \%)$ випадках було пізнє звернення, а 13 (11,9\%) пацієнтів спершу було госпіталізовано в медичний заклад без ангіографа і лише потім перенаправлено в реперфузійний центр. Серед них ПКВ про- 
Огляди літератури, оригінальні дослідження, погляд на проблему, випадок з практики, короткі повідомлення водилося у 93 (85,3 \%) випадках. Середній час з моменту розвитку симптомів до проведення ПКВ становив $(547,58 \pm 176,51 ;$ медіана=300,00) хвилин. Відповідно до існуючих протоколів стосовно тактики ведення пацієнтів зі STEMI, рутинна тромбоаспірація (TA) не $є$ рекомендованою, і тому проводилася лише у випадку повної оклюзії інфарктзалежної артерії та у ситуації вираженого тромбозу [10]. Під час проведення ПКВ ТА була виконана лише у 14 (15,1%) випадках, серед яких було аспіровано зразки тромботичного матеріалу в 12 (12,9\%) пацієнтів і STEMI в перші 12 годин з моменту розвитку больового синдрому.

Аспіровані тромби фіксували в $10 \%$ розчині формаліну та 2,5 \% розчині глутаральдегіду. Процесинг матеріалу відбувався згідно з загальноприйнятими методиками [11]. Забарвлення гістологічних зрізів проводили гематоксиліном-еозином, напівтонких - метиленовим синім. Препарати вивчали за допомогою світлового мікроскопа SEO SCAN та здійснювали фотозйомку за допомогою камери Vision CCD Camera.

При макроскопічному оцінюванні тромбів їх поділяли на 2 групи: «червоні» та «білі»[4] [12]. За результатами світлової мікроскопії виділено три групи тромбів відповідно до їх віку. "Свіжими» вважали ті, які утворилися за 24 години до моменту фіксації. Вони характеризувалися великою кількістю еритроцитів, інтактних нейтрофілів та фібрину. Наступна група «літичних» тромбів віком від 1 до 5 діб відрізнялась наявністю нейтрофілів з явищами дегрануляції та еритроцитами із нечіткими краями, що формували гомогенну масу. Після 5 доби з моменту утворення тромби класифікували як «організовані» із ділянками проростання веретеноподібних клітин та ознаками неоваскуляризації. У випадку, якщо в одному тромбі виділялись ділянки різного віку, то його ідентифікували за найстаршою ділянкою [3, 13-15].

Результати й обговорення. Серед пацієнтів, яким проводилася ТА, переважали чоловіки $\mathrm{n}=10$ (83,3 \%). Середній вік учасників становив $(57,13 \pm 12,92)$ років, час «симптом-балон" $(362,50 \pm 85,43 ; M=155,00)$ хвилин. Більш ніж у половини обстежених була супутня патологія у вигляді гіпертонічної хвороби - $\mathrm{n}=8$ (66,7 \%), а 4 $(33,3 \%)$ пацієнти страждали на цукровий діабет 2-го типу. Курцями були 5 (41,7 \%) осіб.

Надалі проводилась макроскопічна оцінка аспірованого матеріалу. Поділ тромбів на «червоні» та «білі» є одним із найпоширеніших. Традиційно вважають, що «білі» тромби утворюються в артеріальному руслі, а «червоні» більш характерні для судин із нижчою швидкістю кровотоку, щоправда, такий поділ є дуже умовним[16]. Явище атеротромбозу в коронарних артеріях має свої

особливості. Після дестабілізації атеросклеротичної бляшки і експонування в просвіт судини колагену та макрофагів, що несуть на собі тканинний фактор, розпочинається процес формування так званого «білого» тромбу, що складається переважно з тромбоцитів та фібрину [17]. В подальшому кількість фібрину з кожною годиною ішемії починає подвоюватися, а тромбоцитів - пропорційно зменшуватися. В щільній сітці фібрину накопичуються еритроцити і формуються так звані «червоні» тромби [18-19]. Тому «білі» коронарні тромби вважаються молодшими, а «червоні» старшими.

У переважній більшості випадків аспіровані тромби відповідно до макроскопічної оцінки були віднесені до групи «червоних» - n=10 (83,3 \%) (рис. 1). «Білі» тромби зустрічалися рідше - у 2 $(16,7$ \%) пацієнтів, і були отримані лише у разі тривалості больового синдрому менше 2 годин. Також жодного «білого» тромбу не було виявлено у курців. Варто зазначити, що групу "змішаних» тромбів ми в цьому дослідженні не виділяли і визначали належність тромбів відповідно до ділянки, що переважає. Зв'язку між супутньою патологією та макроскопічним видом тромбу нам встановити не вдалося. При зіставленні даних макроскопічної та мікроскопічної оцінок було виявлено, що в структурі «червоних» тромбів очікувано переважали еритроцити та фібрин, також для них більш характерною була наявність периферійної інфільтрації нейтрофілами. Ці результати частково перегукуються з результатами інших робіт $[4,12,20]$.

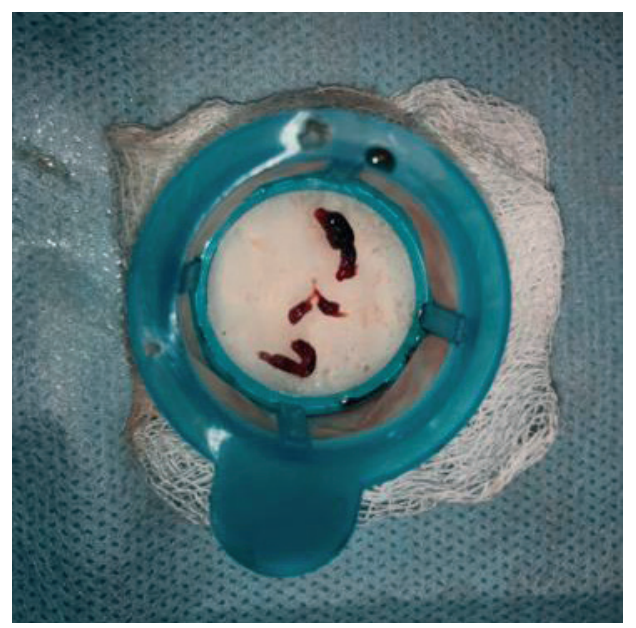

Рис. 1. «Червоні» тромби, отримані після проведення тромбаспірації.

У нашому дослідженні при проведенні світлової мікроскопії у 3 (25,0%) випадках тромби були класифіковані як «свіжі» і характеризувалися пошаровою структурою та інтактними форменими елементами крові (рис. 2). Всі вони були отримані в перші 6 годин з моменту розвитку 
Огляди літератури, оригінальні дослідження, погляд на проблему, випадок з практики, короткі повідомлення больового синдрому. На гістологічному препараті бачимо пошарове розташування депозитів фібрину різного ступеня диференціювання із поодинокими включеннями лейкоцитів без ознак дегрануляції.

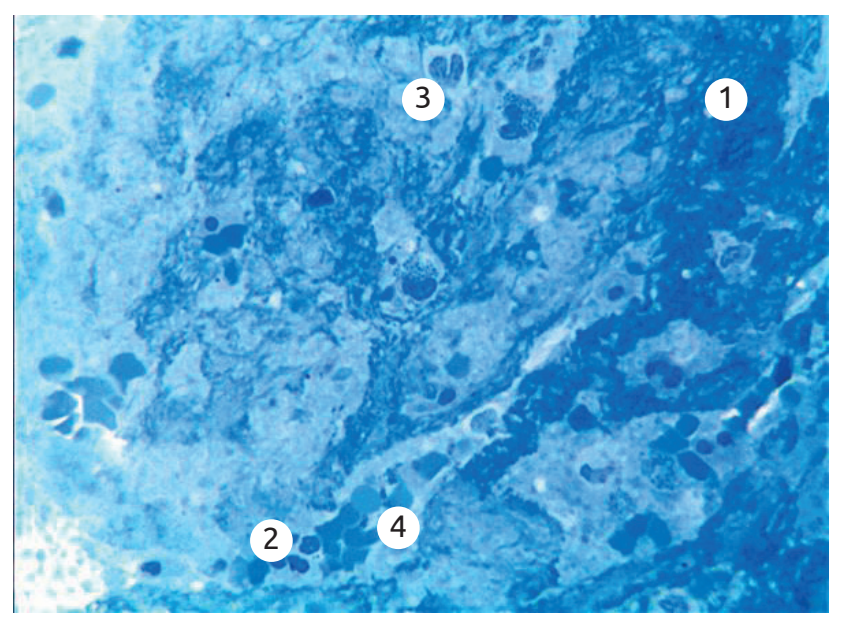

Рис. 2. «Свіжий» тром6: 1 - пошарове розташування фібрину; 2 - поодинокі нейтрофіли; 3 - моноцити; 4 - еритроцити. Забарвлення метиленовим синім. збільшення $\times 400$.

Варто зазначити, що «свіжий» тромб, аспірований через 260 хвилин з моменту розвитку симптомів, відзначався наявністю специфічних форм еритроцитів із специфічною полігональною формою (рис. 3).

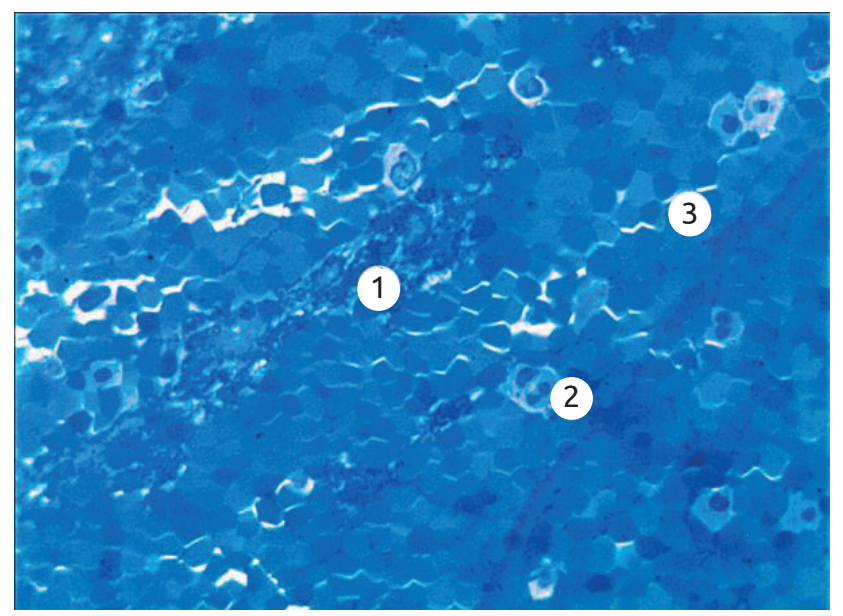

Рис. 3. «Свіжий» тром6: 1 - депозити фібрину; 2 поодинокі сегментоядерні нейтрофіли; 3 - скупчення еритроцитів полігональної форми. Забарвлення метиленовим синім. 36ільшення $\times 400$.

Ïх наявність свідчить про ретракцію тромбу, що відбувається тоді, коли активовані тромбоцити натягують волокна фібрину. Таким чином, тромбоцити та фібрин залишаються переважно на периферії тромбу, а еритроцити зміщуються до його центру. Внаслідок цього класична форма

двоввігнутого диску еритроцитів змінюється на полігональну і такі клітини називають полігедроцитами (polyhedrocytes) [21]. Вони не лише слугують ознакою скорочення тромбу, а й мають прогностичний потенціал, зважаючи на те, що коронарні тромби із значним вмістом полігедроцитів значно краще піддаються тромбаспірації і пов'язані з кращою реперфузією міокарда [22].

Переважали серед усіх зразків аспірованого матеріалу «літичні» тромби, що були виявлені у 7 (58,3 \%) пацієнтів і відрізнялися від групи «свіжих» ознаками гемолізу еритроцитів та дегрануляції нейтрофілів (рис. 4).
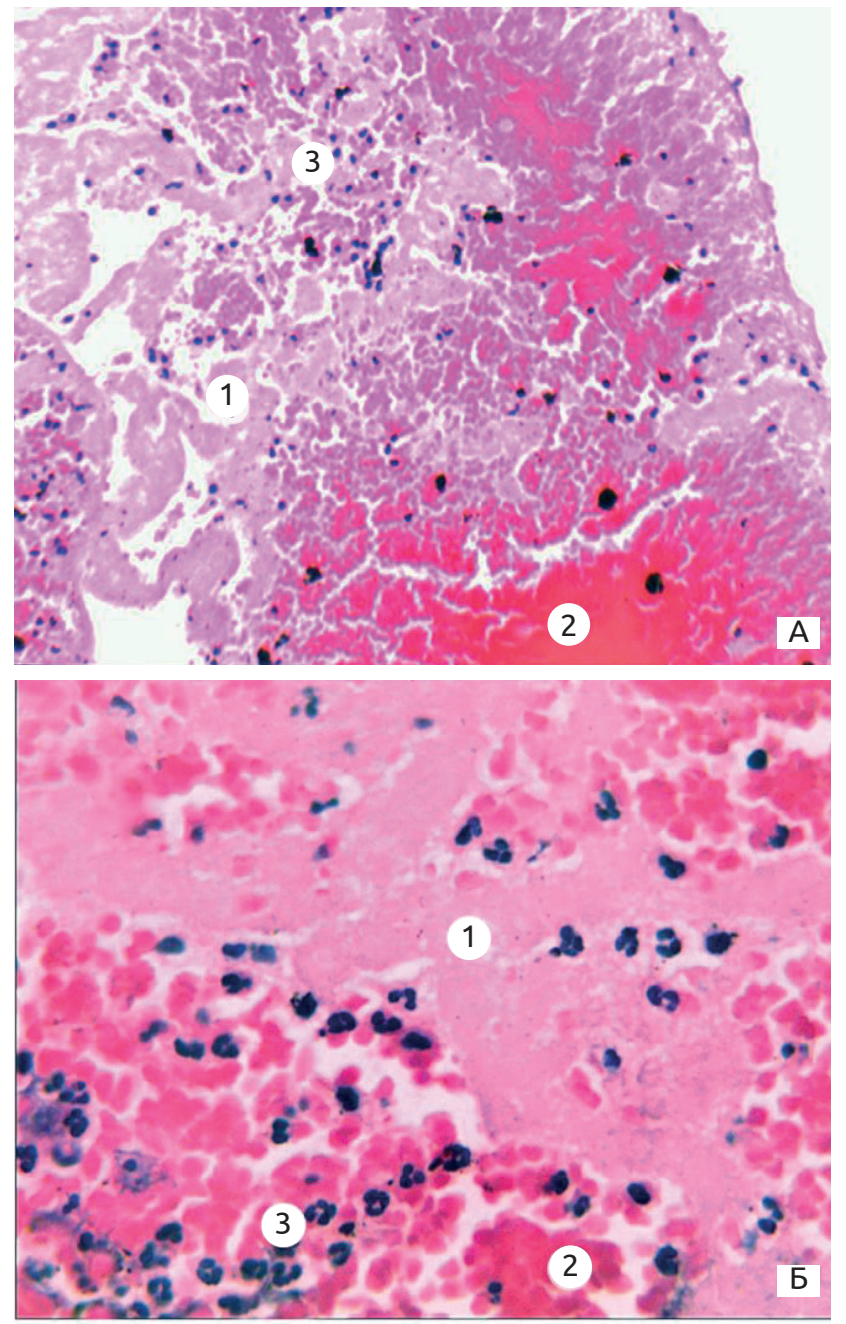

Рис. 4. «Літичний» тромб: 1 - шари фібрину; 2 гемолізовані еритроцити; 3 - лейкоцити. Забарвлення гематоксиліном-еозином. Збільшення × 100 (A), 200 (Б).

Середня тривалість періоду «симптом-балон» у цій групі становила $(376,33 \pm 112,63)$ хвилин, тоді як гістологічний вік "літичних» тромбів становив від 1 до 5 діб.

У 2 (16,7 \%) зразках було виявлено ознаки, характерні для «організованого» тромбу (рис. 5). 
Огляди літератури, оригінальні дослідження, погляд на проблему, випадок з практики, короткі повідомлення
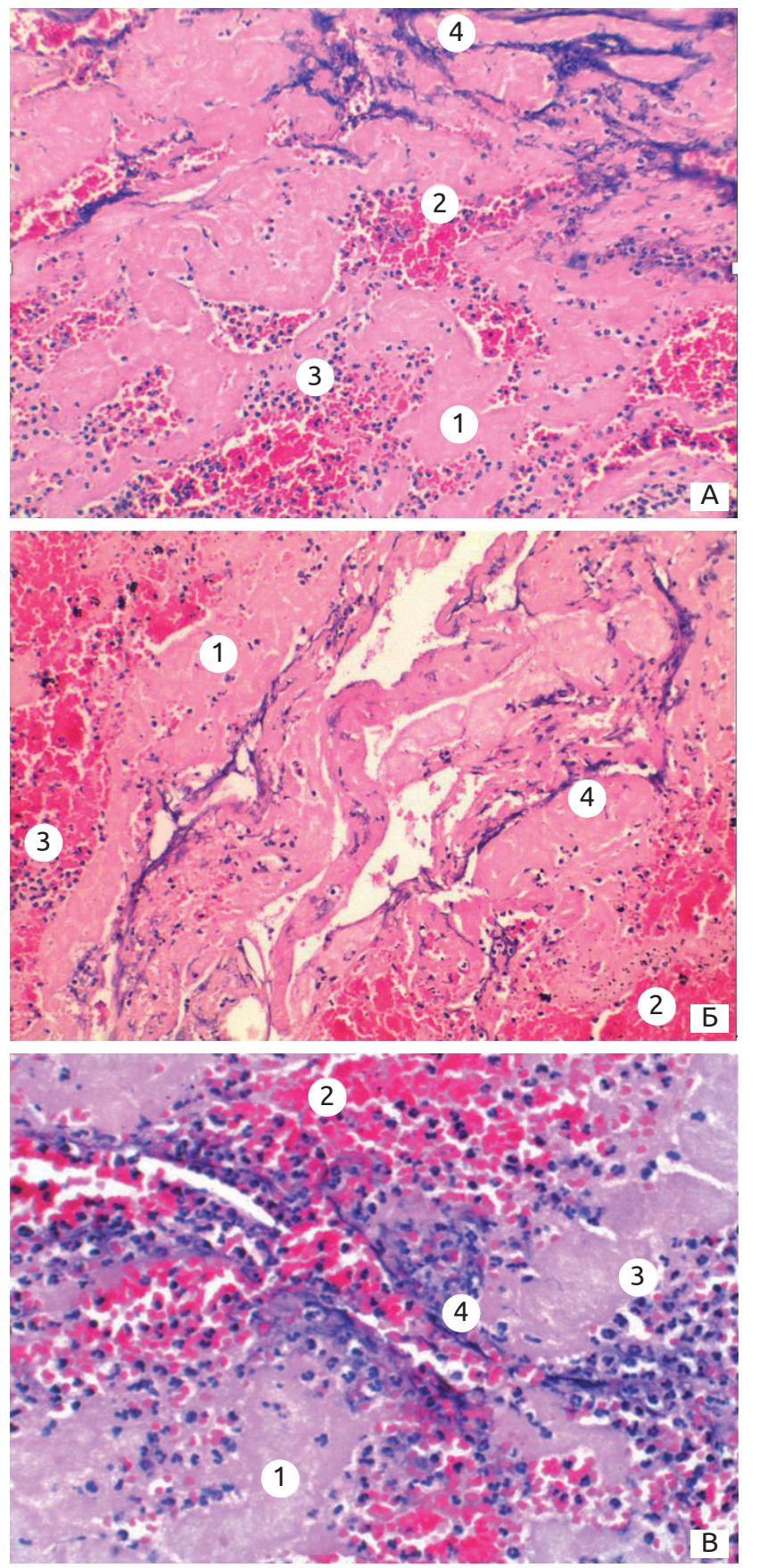

Рис. 5. «Організований» тромб: 1 - шари фібрину; 2 - гемолізовані еритроцити; 3 - лейкоцити; 4 -веретеноподібні клітини. Забарвлення гематоксиліном-еозином. Збільшення × 100 (А, Б), 200 (B).

Поряд із всіма попередніми ознаками, що були характерними для «літичних» тромбів, визнача- ються поодинокі веретеноподібні клітини, що свідчать про початок процесів неоваскуляризації. Загалом, при зіставленні гістологічного віку аспірованих тромбів та часу «симптом-балон», нам не вдалося встановити кореляцію між тривалістю ішемії міокарда та віком тромбів відповідно до гістологічних характеристик. Така тенденція підтверджується рядом досліджень $[6,15,20]$.

У нашому дослідженні при оцінці віддаленого прогнозу лише в одному випадку виявлено епізод повторної госпіталізації з приводу повторного інфаркту міокарда у пацієнта із «червоним» тромбом, який, за результатами світлової мікроскопії, був віднесений до групи «літичних», тобто віком від 1 до 5 днів, незважаючи на тривалість періоду «симптом-балон» близько 3 годин.

Відповідно до літературних даних старші тромби були асоційовані з вищим ризиком серцево-судинних ускладнень [14]. У проспективному двоцентровому дослідженні Nishihira взяли участь 482 пацієнти з ГІМ та було отримано 140 зразків матеріалу, придатних для наступного гістологічного аналізу. 3 метою оцінки прогнозу, окрім мікроструктури тромбів, у мультиваріантний аналіз були включені такі показники як рівень КФК МВ, час «симптом-балон» та ознаки дистальної емболізації, що могли впливати на перебіг післяінфарктного періоду. Навіть враховуючи ці фактори, тромби достовірно частіше призводили до виникнення MACCE в перші 6 місяців з моменту розвитку ГІМ [8]. Схожі результати було отримано і в дослідженні Li X [9]. Варто зазначити, що в цих роботах тромби ділилися за віком лише на 2 групи: «свіжі», що характеризувалися пошаровою структурою еритроцитів, тромбоцитів і фібрину, та "старі», які об'єднували ознаки «літичних» та «організованих» тромбів.

Висновки. При оцінці результатів нашого дослідження чітко прослідковується тенденція до відмінності гістологічного та клінічного віку коронарних тромбів. Це пояснює часту неефективність фібринолітичної терапії, що використовується ніби в межах «терапевтичного вікна», проте не приводить до резолюції сегмента ST. Крім того, вдалося попередньо підтвердити існування зв'язку між структурою аспірованих тромбів та потенційним прогнозом перебігу гострого інфаркту міокарда, в тому числі й розвитку ускладнень у віддаленій перспективі. 


\section{ЛІТЕРАТУРА}

1. Global epidemiology of ischemic heart disease: results from the global burden of disease study / M. A. Khan, M. J. Hashim, H. Mustafa [et al.] // Cureus. 2020. - Vol. 12 (7). - e9349.

2. Hansson G. K. Inflammation and plaque vulnerability / G. K. Hansson, P. Libby, I. Tabas // J. Intern. Med. 2015. - Vol. 278 (5). - P. 483-493.

3. Plaque instability frequently occurs days or weeks before occlusive coronary thrombosis: a pathological thrombectomy study in primary percutaneous coronary intervention / S. Z. Rittersma, A. C. van der Wal, K. T. Koch [et al.] // Circulation. - 2005. - Vol. 111 (9). - P. 1160-1165.

4. Thrombus aspirated from patients with ST-elevation myocardial infarction: Clinical and angiographic outcomes / Y. Yang, J. Li, W. Xu [et al.] // J. Int. Med. Res. 2016. - Vol. 44 (6). - P. 1514-1523.

5. Оцінка зв'язків між морфологічними особливостями інтракоронарних тромбів та структурно-функціональним станом лівого шлуночка в пацієнтів з інфарктом міокарда з елевацією сегмента ST / Д. Д. Зербіно, Д. І. Беш, М. Ю. Соколов, О. М. Беш // Медичні перспективи. - 2020. - Т. 25, №. 3. - С. 62-70.

6. Морфологическое исследование тромбов, аспирированных из инфарктзависимой коронарной артерии у пациентов с острым инфарктом миокарда / Ю. Н. Соколов, М. Ю. Соколов, Д. Д. Зербино [та ін.] // Серце і судини. - 2015. - № 44. - С. 7-15.

7. Organized thrombus in aspirated coronary materials can predict in-hospital mortality of patients with acute myocardial infarction / K. Nishihira, K. Hatakeyama, Y. Shibata [et al.] // Circ. J. - 2013. - Vol. 77 (5). - P. 1275-1280.

8. Relationship between thrombus age in aspirated coronary material and mid-term major adverse cardiac and cerebrovascular events in patients with acute myocardial infarction / K. Nishihira, Y. Shibata, A. Yamashita [et al.] // Atherosclerosis. - 2018. - Vol. 268. - P. 138-144.

9. Older coronary thrombus is an independent predictor of 1-year mortality in acute myocardial infarction / X. Li, M. C. Kramer, P. Damman [et al.] // Eur. J. Clin. Invest. - 2016. - Vol. 46 (6). - P. 501-510.

10. 2017 ESC Guidelines for the management of acute myocardial infarction in patients presenting with ST-segment elevation: The Task Force for the management of acute myocardial infarction in patients presenting with STsegment elevation of the European Socie / B. Ibanez, S. James, S. Agewall [et al.] // Eur. Heart J. - 2018. Vol. 39 (2). - P. 119-177.

11. Горальський Л. П. Основи гістологічної техніки і морфофункціональні методи дослідження у нормі та при патології: навчальний посібник / Л. П. Горальський, В. Т. Хомич, О. І. Кононський. - Житомир : ЖНАЕУ, 2019. $286 \mathrm{C}$.

\section{REFERENCES}

1. Khan, M.A., Hashim, M.J., Mustafa, H., Baniyas, M.Y., Al Suwaidi, S.K.B.M., AlKatheeri, R., \& Lootah, S.N.A.H. (2020). Global epidemiology of ischemic heart disease: results from the global burden of disease study. Cureus, 12 (7), e9349. DOI: 10.7759/cureus.9349
12. Red versus white thrombi in patients with ST-elevation myocardial infarction undergoing primary percutaneous coronary intervention: Clinical and angiographic outcomes / A. S. Quadros, E. Cambruzzi, J. Sebben [et al.] // Am. Heart J. - 2012. - Vol. 164 (4). - P. 553-560.

13. Thrombus aspiration therapy and coronary thrombus components in patients with acute ST-elevation myocardial infarction / K. Yunoki, T. Naruko, K. Sugioka [et al.] // J. Atheroscler. Thromb. - 2013. - Vol. 20 (6). P. 524-537.

14. Histopathological features of aspirated thrombi after primary percutaneous coronary intervention in patients with ST-elevation myocardial infarction / M. C. Kramer, A. C. van der Wal, K. T. Koch [et al.] // PLoS One. - 2009. Vol. 4 (6). - P. e5817.

15. Histopathology of aspirated thrombi during primary percutaneous coronary intervention in patients with acute myocardial infarction / I. Šteiner, J. Špaček, A. Matějková [et al.] // Cardiovasc. Pathol. - 2014. - Vol. 23 (5). P. 267-271.

16. The distinctive structure and composition of arterial and venous thrombi and pulmonary emboli / I. N. Chernysh, C. Nagaswami, S. Kosolapova [et al.] // Sci. Rep. 2020. - Vol. 10 (1). - 5112.

17. Pathophysiology of atherothrombosis: Mechanisms of thrombus formation on disrupted atherosclerotic plaques / Y. Asada, A. Yamashita, Y. Sato, K. Hatakeyama // Pathol. Int. - 2020. - Vol. 70 (6). - P. 309-322.

18. Thrombus composition in sudden cardiac death from acute myocardial infarction / J. Silvain, J. P. Collet, P. Guedeney [et al.] // Resuscitation. - 2017. - Vol. 113. P. 108-114.

19. Composition of coronary thrombus in acute myocardial infarction / J. Silvain, J. P. Collet, C. Nagaswami [et al.] // J. Am. Coll. Cardiol. - 2012. - Vol. 57 (12). P. 1359-1367.

20. Assessing composition of coronary thrombus in STEMI patients a multiscale approach to charaterize samples obtained by catheter aspiration / F. Tessarolo, E. Bonomi, F. Piccoli [et al.] // Proceedings of the 2nd International Congress on Cardiovascular Technologies (CARDIOTECHNIX-2014). - SCITEPRESS (Science and Technology Publications, Lda.), 2014. - P. 5-12

21. Shape changes of erythrocytes during blood clot contraction and the structure of polyhedrocytes / V. Tutwiler, A. R. Mukhitov, A. D. Peshkova [et al.] //Sci. Rep. - 2018. Vol. 8 (1). - 17907. DOI: 10.1038/s41598-018-35849-8.

22. Polyhedral erythrocytes in intracoronary thrombus and their association with reperfusion in myocardial infarction / V. Tutwiler, A. R. Mukhitov, A. D. Peshkova [et al.] // Clin. Res. Cardiol. - 2019. - Vol. 108 (8). P. 950-962.

2. Hansson, G.K., Libby, P., \& Tabas, I. Inflammation and plaque vulnerability. J. Intern. Med., 278 (5), 483-493. DOI: 10.1111/joim.12406

3. Rittersma, S.Z., van der Wal, A.C., Koch, K.T., Piek, J.J., Henriques, J.P., Mulder, K.J., \& de Winter, R.J. (2005). 
Огляди літератури, оригінальні дослідження, погляд на проблему, випадок з практики, короткі повідомлення Plaque instability frequently occurs days or weeks before occlusive coronary thrombosis: A pathological thrombectomy study in primary percutaneous coronary intervention. Circulation, $111(9), 1160-1165$. DOI: 10.1161/ 01. CIR.0000157141.00778.AC

4. Yang, Y., Li, J., Xu, W., Dong, S., Yu, H., Song, H., \& Chu, Y. (2016). Thrombus aspirated from patients with ST-elevation myocardial infarction: Clinical and angiographic outcomes. J. Int. Med. Res., 44 (6), 1514-1523. DOI: $10.1177 / 0300060516667373$

5. Zerbino, D.D., Besh, D.I., Sokolov, M.Yu., \& Besh, O.M. (2020). Otsinka zviazkiv mizh morfolohichnymy osoblyvostiamy intrakoronarnykh trombiv ta strukturnofunktsionalnym stanom livoho shlunochka $v$ patsiientiv $z$ infarktom miokarda z elevatsiieiu sehmenta ST [Correlations between morphological features of intracoronary thrombi and left ventricular structure and function in patients with ST-segment elevation myocardial infarction]. Medycni perspektyvy - Medical prospects, 25 (3), 61-70. DOI: https://doi.org/10.26641/2307-0404.2020.3.214808 [in Ukrainian].

6. Sokolov, Yu.M., Sokolov, M.Yu., Zerbino, D.D., Bisyarin, Yu.V., \& Besh, D.I. (2015). Morfolohycheskoe yssledovanye trombov, apsyryrovannykh yz ynfarktzavysymoi koronarnoi arteryy u patsyentov s ostrim infarktom myokarda [Morphological thrombus examination after aspiration from infarct-related coronary artery in patients with acute myocardial infarction]. Sertse $i$ sudyny - Heart and Vessels, 44, 7-15 [in Ukrainian].

7. Nishihira, K., Hatakeyama, K., Shibata, Y., Kitamura, K., \& Asada, Y. (2013). Organized thrombus in aspirated coronary materials can predict in-hospital mortality of patients with acute myocardial infarction. Circ. J., $77(5)$, 1275-1280. DOI: 10.1253/circj.CJ-12-0911

8. Nishihira, K., Shibata, Y., Yamashita, A., Kuriyama, N., \& Asada, Y. (2018). Relationship between thrombus age in aspirated coronary material and mid-term major adverse cardiac and cerebrovascular events in patients with acute myocardial infarction. Atherosclerosis, 268, 138-144. DOI: 10.1016/j.atherosclerosis.2017.12.001

9. Li, X., Kramer, M.C., Damman, P., van der Wal, A.C., Grundeken, M.J., van Straalen, J.P., ..., \& de Winter, R.J. (2016). Older coronary thrombus is an independent predictor of 1-year mortality in acute myocardial infarction. Eur. J. Clin. Invest., 46 (6), 501-510. DOI: 10.1111/eci.12619

10. Ibanez, B., James, S., Agewall, S., Antunes, M.J., Bucciarelli-Ducci, C., Bueno, H., \& Widimský, P. (2018). 2017 ESC Guidelines for the management of acute myocardial infarction in patients presenting with ST-segment elevation: The Task Force for the management of acute myocardial infarction in patients presenting with ST-segment elevation of the European Socie. Eur. Heart J., 39 (2), 119177. DOI: 10.1093 /eurheartj/ehx393

11. Horalskyi, L.P., \& Khomych, V.T. (2019). Osnovy histolohichnoi tekhniky i morfo-funktsionalni metody doslidzhennia u normi ta pry patolohii [Fundamentals of histological technique and morpho-functional research methods in normal and pathology]. Zhytomyr National Agroecological University [in Ukrainian].

12. Quadros, A.S., Cambruzzi, E., Sebben, J., David, R.B., Abelin, A., Welter, D., \& Lopes, R.D. (2012). Red versus white thrombi in patients with ST-elevation myocardial infarction undergoing primary percutaneous coronary intervention: Clinical and angiographic outcomes. Am. Heart J., 164 (4), 553-560. DOI: 10.1016/j.ahj.2012.07.022

13. Yunoki, K., Naruko, T., Sugioka, K., Inaba, M., Itoh, A., Haze, K., \& Ueda, M. (2013). Thrombus aspiration therapy and coronary thrombus components in patients with acute ST-elevation myocardial infarction. J. Atheroscler. Thromb., 20 (6), 524-537. DOI: 10.5551/jat.17608

14. Kramer, M.C., van der Wal, A.C., Koch, K.T., Rittersma, S.Z., Li, X., Ploegmakers, H.P., \& Winter, R.J. (2009). Histopathological features of aspirated thrombi after primary percutaneous coronary intervention in patients with ST-elevation myocardial infarction. PLoS One, 4 (6), e5817. DOI: 10.1371/journal.pone.0005817

15. Šteiner, I., Špaček, J., Matějková, A., Vojáček, J., Bis, J., \& Dušek, J. (2014). Histopathology of aspirated thrombi during primary percutaneous coronary intervention in patients with acute myocardial infarction. Cardiovasc. Pathol., 23 (5), 267-271. DOI: 10.1016/j.carpath.2014.04.006

16. Chernysh, I.N., Nagaswami, C., Kosolapova, S., Peshkova, A.D., Cuker, A., Cines, D.B., \& Weisel, J.W. (2020). The distinctive structure and composition of arterial and venous thrombi and pulmonary emboli. Sci. Rep., 10 (1), 5112. DOI: $10.1038 / \mathrm{s} 41598-020-59526-x$

17. Asada, Y., Yamashita, A., Sato, Y., \& Hatakeyama, K. (2020). Pathophysiology of atherothrombosis: Mechanisms of thrombus formation on disrupted atherosclerotic plaques. Pathol. Int., 70 (6), 309-322. DOI: 10.1111/pin.12921

18. Silvain, J., Collet, J.P., Guedeney, P., Varenne, O., Nagaswami, C., Maupain, C., \& Spaulding, C. (2017). Thrombus composition in sudden cardiac death from acute myocardial infarction. Resuscitation, 113, 108-114. DOI: https:// doi.org/10.1016/j.resuscitation.2017.01.030

19. Silvain, J., Collet, J.P., Nagaswami, C., Beygui, F., Edmondson, K.E., Bellemain-Appaix, A., \& Weisel, J.W. (2012). Composition of coronary thrombus in acute myocardial infarction. J. Am. Coll. Cardiol., 57 (12), 1359-1367. DOI: 10.1016/j.jacc.2010.09.077

20. Tessarolo, F., Bonomi, E., Piccoli, F., Morat, F., Rigoni, M., Caola, I., \& Nollo, G. (2014). Assessing composition of coronary thrombus in STEMI patients: a multiscale approach to charaterize samples obtained by catheter aspiration. In Proceedings of the 2nd International Congress on Cardiovascular Technologies (CARDIOTECHNIX-2014). SCITEPRESS (Science and Technology Publications, Lda.), (pp. 5-12). DOI: 10.5220/0005144600050012

21. Tutwiler, V., Mukhitov, A.R., Peshkova, A.D., Le Minh, G., Khismatullin, R.R., Vicksman, J., \& Weisel, J.W. Shape changes of erythrocytes during blood clot contraction and the structure of polyhedrocytes. Sci. Rep., 8 (1), 17907. DOI: $10.1038 / \mathrm{s} 41598-018-35849-8$

22. Tutwiler, V., Mukhitov, A.R., Peshkova, A.D., Le Minh, G., Khismatullin, R.R., Vicksman, J., \& Weisel, J.W. (2019). Polyhedral erythrocytes in intracoronary thrombus and their association with reperfusion in myocardial infarction. Clin. Res. Cardiol., 108 (8), 950-962. DOI: 10.1007/ s00392-019-01425-x 


\title{
Огляди літератури, оригінальні дослідження, погляд на проблему, випадок з практики, короткі повідомлення \\ РЕЗУЛЬТАТЫ ГИСТОЛОГИЧЕСКОГО АНАЛИЗА ТРОМБОВ, ПОЛУЧЕННЫХ ВО ВРЕМЯ ПРОВЕДЕНИЯ ЧРЕСКОЖНОГО КОРОНАРНОГО ВМЕШАТЕЛЬСТВА: МОРФОЛОГИЧЕСКИЕ И КЛИНИЧЕСКИЕ ПАРАЛЛЕЛИ
}

\author{
๑М. В. Гребеник, Д. В. Жегестовская, З. М. Небесная, С. Б. Крамар
}

Тернопольский национальный медицинский университет имени И. Я. Горбачевского МОз Украины

РЕЗЮМЕ. В основе патогенеза острого коронарного синдрома лежит дестабилизация атеросклеротической бляшки с последующим тромбозом коронарной артерии. С введением в клиническую практику чрескожных коронарных вмешательств появилась возможность не только быстро и эффективно восстанавливать проходимость инфаркт-зависимого сосуда, но и прижизненно исследовать структуру коронарных тромбов. Эта информация является ценной как для углубления понимания патогенеза острых коронарных событий, так и для прогноза их дальнейшего течения.

Цель - сопоставить клинические данные и гистологическую структуру тромбов у пациентов с острым инфарктом миокарда (ОИМ).

Материал и методы. В исследовании приняли участие 109 пациентов с диагнозом ОИМ. Пригодный для гистологического исследования материал был получен в 12 случаях. В соответствии с этим проводился анализ образцов с определением гистологического возраста аспирированных тромбов, а также сопоставление их морфологических характеристик и клинических данных пациентов.

Результаты. В большинстве случаев аспирированные тромбы по макроскопическим показателям были отнесены к группе «красных» - n=10 (83,3 \%). «Белые» тромбы встречались реже - в 2 (16,7 \%) случаях, и были получены лишь при продолжительности болевого синдрома меньше 2 часов. По данным световой микроскопии в 3 (25,0 \%) случаях тромбы классифицировались как «свежие», все они были получены в первые 6 часов с момента развития болевого синдрома. «Литические» тромбы выявлены у 7 (58,3 \%) пациентов и в 2 (16,7 \%) образцах отмечались признаки, характерные для «организованных» тромбов. При оценке отдаленного прогноза только в одном случае был эпизод повторной госпитализации из-за повторного инфаркта миокарда у пациента с «красным» тромбом, который, по результатам световой микроскопии, был отнесен к группе «литических», то есть в возрасте от 1 до 5 дней, несмотря на продолжительность периода «симптом-баллон» около 3 часов.

Выводы. Нами было выявлено несоответствие гистологического и клинического возраста коронарных тромбов. Также удалось предварительно подтвердить существование связи между структурой аспирированных тромбов и потенциальным прогнозом течения острого инфаркта миокарда, в том числе и развития осложнений в отдаленной перспективе.

КЛЮЧЕВЫЕ СЛОВА: острый инфаркт миокарда; коронарный тромб; морфологические характеристики тромбов; чрескожное перкутанное вмешательство.

\section{HISTOLOGICAL ANALYSIS OF THROMBI OBTAINED DURING PERCUTANEOUS CORONARY INTERVENTION: MORPHOLOGICAL AND CLINICAL INTERACTIONS}

\author{
@M. V. Hrebenyk, D. V. Zhehestovska, Z. M. Nebesna, S. B. Kramar \\ I. Horbachevsky Ternopil National Medical University
}

SUMMARY. The pathogenesis of acute coronary syndrome is based on the destabilization of atherosclerotic plaque with subsequent thrombosis of the coronary artery. With the introduction of percutaneous coronary interventions in clinical practice it became possible not only to quickly and effectively restore the patency of the infarct-dependent artery, but also to investigate the structure of coronary thrombi in vivo. This information is valuable both for deepening the understanding of the pathogenesis of acute coronary events and for predicting their further course.

The aim - to compare clinical data and histological structure of thrombi in patients with acute myocardial infarction (AMI).

Material and Methods. The study involved 109 patients diagnosed with AMI. Material suitable for histological examination was obtained in 12 cases. Samples were analyzed to determine the histological age of aspirated thrombi, as well as to compare their morphological characteristics and clinical data of patients.

Results. In most cases, aspirated blood clots by macroscopic parameters were classified as "red" - n=10 (83,3\%). "White" blood clots appeared less common - in $2(16.7 \%)$ cases, and were obtained only if the angina pectoris lasted less than 2 hours. According to microscopy analysis in $3(25,0 \%)$ cases, blood clots were classified as "fresh", all of them were obtained in the first 6 hours after the development of chest pain. "Lytic" thrombi were found in 7 (58,3\%) patients and in 2 (16,7 \%) samples there were signs of "organized" blood clots. When assessing the long-term prognosis in only one case was an episode of re-hospitalization for recurrent myocardial infarction in a patient with a "red" thrombus, which according to microscopy analysis was classified as "lytic", ie aged 1 to 5 days, despite the length of the period "symptom-balloon" about 3 hours.

Conclusions. We found a discrepancy between the histological and clinical age of coronary thrombi. It was also possible to confirm the existence of a connection between the structure of aspirated thrombi and the potential prognosis of acute myocardial infarction, including the development of complications in the long run.

KEY WORDS: acute myocardial infarction; coronary thrombus; morphological characteristics of thrombi; percutaneous coronary intervention. 